\title{
SWOT ON BT COTTON GROWERS IN NAGPUR DISTRICT OF MAHARASHTRA
}

\author{
L. RAJA ${ }^{1} \&$ V.S. TEKALE ${ }^{2}$ \\ ${ }^{1}$ Research Scholar, Division of Dairy Extension, NDRI, Karnal, India \\ ${ }^{2}$ Associate Professor, Department. of Extension Education, College of Agriculture, Nagpur, India
}

\begin{abstract}
The present study was aimed at knowing the SWOT on Bt cotton Growers in Bt cotton cultivation in Nagpur District of Maharashtra in the year 2014-2016 with 120 respondent Bt cotton growers. The major strengths of BT cotton growers in BT cotton cultivation are - reduced pesticide sprays for bollworm, followed by better bollworm control. The major Weaknesses are - Bt crop requires more number of sprays for managing sucking pests, followed by emergence of new pests and diseases like pink bollworm, mealy bugs, tobacco streak virus, cucumber mosaic virus, grey mildew, wilt, etc. The major opportunities are - availability of seed in time, followed by availability of seed in sufficient quantities. The major threats are - highly dependent on private company's forseed, followed by fluctuations in market prices.

KEYWORDS: Boll Worm, Bt-Cotton, Cotton Growers \& SWOT
\end{abstract}

Received: May 12, 2017; Accepted: May 27, 2017; Published: May 30, 2017; Paper Id.: IJASRJUN201740

\section{INTRODUCTION}

The revolutionary change is attributed to the introduction of $B t$ cotton in the farm fields of India. Cotton farmers in India, who had once given up cotton cultivation due to unaffordable costs of production and expensive and ineffective pest control, have returned to the crop since 2002. This change is also often referred to as the White Gold Revolution in the country.

$B T$ cotton, the single major factor that increased cotton acreage in India also faces several criticisms on the other hand. A number of groups from the civil society contest its effectiveness and report that a group of farmers have lost income using it, needing more pesticide and obtaining lower yields. Other groups report its toxic effects on domestic animal health. Many producer and activist groups contest the very high cost of seeds of $B t$ cotton. Yet, perhaps the most talked about controversy relates to the alleged resurgence of cotton farmer suicides in certain Indian states and their relationship with use of $B t$ cotton.

India has a well-defined system comprising of six committees constituted by the Government of India to evaluate biosafety and regulate GM crops. Two of these, the Recombinant DNA Advisory Committee (RDAC) and the Review Committee on Genetic Manipulation (RCGM) are under the Department of Bio-technology. The main approving body, the Genetic Engineering Approval Committee (GEAC) is under the Ministry Environment and Forests. The Institutional Biosafety Committee (IBSC) in internal to technology developers and prepares sitespecific plans for use of genetically engineered microorganisms. The RCGM lays down procedures/regulations regarding conducting and monitoring research, production, sale, import and use of genetically engineered organisms with a view to ensure environmental safety, while the GEAC finally approves the release of genetically engineered organisms into the environment. The State Bio-technology Coordination Committees (SBCC) and the District Level Committees (DLC) inspect, investigate and take punitive action in case of violations of safety and control 
measures in the handling of genetically engineered organisms.

The investigation majorly deals with SWOT analysis of $B t$ cotton Growers in $B t$ cotton cultivation. After SWOT analysis of $B T$ cotton growers we can identify the Strengths, Weaknesses, Opportunities and Threats in Bt cotton cultivation.

Mukunda Rao (2011) revealed the major strengths of $B t$ cotton cultivation as perceived by the $B t$ cotton growers were higher yields, higher net income and reduction in the total number of pesticide sprays against boll worms and better boll worm control followed by good quality cotton lint from $B t$ cotton, reduced exposure of the farmers, farm workers and environment to pesticides due to the reduction of pesticide sprays and high price in the market.

Prathyusha (2014) noticed that weaknesses perceived by the $B t$ cotton growers were poor performance in rainfed conditions followed by emergence of new pests and diseases mealy bugs, Tobacco streak virus, cucumber mosaic virus, grey mildew, wilt, $B t$ crop requires more number of sprays for managing sucking pests than the non-Bt crop, micronutrient deficiencies, health problems among human beings like irritation while picking, allergies etc, yield reduction, death and health problems in cattle, $B t$ cotton crop is soil exhausting, subsequent crop will not come up healthy.

Ahsan Abdullah (2010) reported that reduction in the use of broad-spectrum pesticides on Bt cotton would result in conservation of natural enemies as well as a decrease in soil and water conservation. Moreover, a reduction in pesticide usage will also bring health benefits to female Pakistani cotton pickers and others who come in contact with these pesticides.

Jog ender Singh (2013) expressed high seed cost to be an important problem followed by lack of package of practices of SAU (70.83\%), lack of pure and quality seeds of $B t$ cotton (68.33\%) and lack of agricultural labour during peak season $(67.50 \%)$.

\section{MATERIAL AND METHODS}

Exploratory research design was used in the present investigation. The study was conducted in Nagpur district of Maharashtra, from the selected district two tahsils were namely Kalmeshwar and Saoner selected purposively based on highest area under Bt cotton cultivation and from each selected tahsils, six villages were selected randomly, 10 respondent Bt-cotton growers were selected randomly from each village making total 120 respondents. Kalmeshwar and Saoner tahsils are situated in north east side of Nagpur at a distance of $23 \mathrm{~km}$ and $36 \mathrm{~km}$, respectively.

Kalmeshwar tahsil consist of 108 villages and total population is $1,14,400$ according to census 2011. The total geographical of this tahsil is 50,343 ha, out of which total cultivated area are 35,985 ha. The average rainfall is $922 \mathrm{~mm}$. The major crops grown in this area are orange, cotton, soyabean, jowar, tur, mung, chilli and vegetables in kharif season and wheat, gram, sunflowers, vegetables in rabi season.

Saoner tahsil consist of 136 villages and total population is 2,23,165 according to census, 2011. The total geographical of this tahsil is 1,11,633 ha, out of which total cultivated area is 79,150 ha. The major crops grown in this area are cotton, soyabean, jowar, orange, tur, mung, chilli and vegetables in kharif season and wheat, gram and vegetables in rabi season. 


\section{RESULTS AND DISCUSSIONS}

\section{RBQ-Strengths}

The strengths perceived by Bt cotton growers in Bt cotton cultivation were- reduced pesticide sprays for bollworm, followed by better bollworm control (81.75\%), significant yield increase (79.66\%), higher net income (74.66\%), reduced cost of cultivation (71.00\%), more number of bolls (50.75\%), good quality of cotton lint and kapas (31.83\%), reduced exposure of the farmers and farm workers to pesticides (26.91\%), short duration crop facilitating sequence crop $(25.66 \%)$ and saving on labours $(22.00 \%)$, respectively.

Reduced pesticide sprays for bollworm coupled with bollworm control and significant yield increase is a welcoming strength in $B t$ cotton cultivation. Hence it is the need of hour to conduct Farming Situation Based Research and Extension (FSBRE) to make $B t$ cotton cultivation profitable.

\section{RBQ-Weaknesses}

The Weaknesses expressed by Bt cotton growers in Bt cotton cultivation were

$B t$ crop requires more number of sprays for managing sucking pests, followed by emergence of new pests and diseases like pink bollworm, mealy bugs, tobacco streak virus, cucumber mosaic virus, grey mildew, wilt, etc (82.75\%), poor performance in rain fed condition $(80.40 \%)$, micronutrient deficiencies $(79.00 \%)$, health problems among human beings like irritation while picking, allergies, etc. (66.25\%) and Bt require more number of irrigations (41.00\%), respectively. The other weaknesses perceived were $B t$ cotton is more susceptible to drought (31.66\%), $B t$ cotton crop is soil exhausting, subsequent crop will not come up healthy $(29.58 \%)$, yield reduction $(27.41 \%)$ and death and health problems in cattle $(23.66 \%)$.

The more number of spraying to $B t$ cotton, emergence of new pests and diseases, poor performance in rain fed and micronutrient deficiencies were major weaknesses perceived by $B t$ cotton growers. Hence researcher has to be developing the specific packages for management of newly emerging pest and diseases like pink boll warm tobacco streak virus, cucumber mosaic virus, mealy bugs, grey mildew and wilt.

\section{RBQ-Opportunities}

Opportunities of Bt cotton growers in Bt cotton cultivation were- availability of seed in time, followed by availability of seed in sufficient quantities (85.99\%), availability of good quality seed (82.24\%), high price in the market (77.25\%) and $B t$ cotton is environment friendly as it reduces pesticide usage (62.32\%), respectively. The other opportunities perceived by $B t$ cotton growers were good access to institutional credit (39.16\%), cultivation of $B t$ cotton reduces pesticide poisoning cases (27.49), good extension support (26.56\%), scope for developing many crops with $B t$ technology (26.24\%) and savings on labour (15.58\%).

The major opportunities for $B t$ cotton growers were timely, sufficient quantity and high quality availability of $B t$ cotton seed, high price to $B t$ cotton in market and $B t$ cotton is environment friendly and its reduces pesticide use.

\section{RBQ-Threats}

Treats faced by Bt cotton growers in Bt cotton cultivation were- highly dependent on private companies for seed, followed by fluctuations in market prices $(84.16 \%)$, high cost of $B t$ cotton seed (81.83\%), defective government policies (74.31\%), defective rehabilitation package (58.49\%), lack of $B t$ cotton hybrids released by SAU (51.54\%), respectively. 
The other threats were less minimum support price (38.16\%), availability spurious seeds (35.8\%) and availability of illegal seeds sold by unlicensed companies $(23.81 \%)$.

The high dependence on private companies for seeds and lack of $B t$ cotton hybrids released by public sector is an alarming threat found in the study, as complete dependence of farmers (especially small and marginal) on Multi National Companies (MNC'S) might lead to certain undesirable social implications. Hence corrective measures are to be taken by the government in stabilizing the market price and curbing the menace of illegal companies. Public research institutions should be supported for release of Bt cotton hybrids and their subsequent multiplication and large scale cultivation.

\section{CONCLUSIONS}

It could be concluded from the study the major strengths of Bt cotton growers in Bt cotton cultivation were reduced pesticide sprays for bollworm, followed by better bollworm control. The major Weaknesses were - Bt crop requires more number of sprays for managing sucking pests, followed by emergence of new pests and diseases like pink bollworm, mealy bugs, tobacco streak virus, cucumber mosaic virus, grey mildew, wilt, etc .The major opportunities were availability of seed in time, followed by availability of seed in sufficient quantities. The major threats were - highly dependent on private companies for seed, followed by fluctuations in market prices.

\section{REFERENCES}

1. Ahsan Abdullah, 2010. "An Analysis of Bt Cotton Cultivation in Punjab, Pakistan Using the Agriculture Decision Support System (ADSS)." AgBioForum, 13(3): 274-287.

2. Jogender Singh, 2013. Adoption of Bt cotton technologies and constraints faced by cotton growers in Haryana. Journal of Cotton Research Development 27 (1) 149-151

3. Mukunda Rao, B. 2011. An analysis study on BT cotton cultivation in Andhra Pradesh. Ph.D Thesis (unpub.) Acharya N.G. Ranga Agricultural University, Hyderabad, India.

4. Prathyusha, T. 2014. A study on SWOT analysis of Bt cotton cultivation in Karimnagar district of Andhra Pradesh. M.Sc. (Agri.) Thesis (unpub) Acharya N.G. Ranga Agricultural University, Hyderabad India. 